\title{
Assessment of the impacts of climate change and weather extremes on boreal forests in northern Europe, focusing on Norway spruce
}

\author{
Peter Schlyter $^{1, *}$, Ingrid Stjernquist ${ }^{1}$, Lars Bärring ${ }^{2}$, Anna Maria Jönsson ${ }^{3}$, Carin Nilsson ${ }^{2}$ \\ ${ }^{1}$ Department of Physical Geography and Quaternary Geology, Stockholm University, 10691 Stockholm, Sweden \\ ${ }^{2}$ Geobiosphere Science Centre, Department of Physical Geography and Ecosystems Analysis, Lund University, Sölvegatan 12, \\ 22362 Lund, Sweden \\ ${ }^{3}$ Department of Ecology, Plant Ecology and Systematics, Lund University, Ecology Building, 223 62 Lund, Sweden
}

\begin{abstract}
The boreal and boreo-nemoral forests in Europe, which occur in northern and northeastern Europe, are dominated by 2 coniferous species, Norway spruce Picea abies (L.) Karst. being economically the most important one. Forestry is of major economic importance in this region. Forestry planning and climate change scenarios are based on similar (long-term) timescales, i.e. between 70 and 120 yr. Within the EU project 'Modelling the Impact of Climate Extremes' (MICE), we have used 'present day' runs (1961-1990) and future scenarios (2070-2100, emission scenarios A2 and B2 from the Special Report on Emissions Scenarios [SRES]) of the HadRM3 regional climate model to study and model direct and indirect effects of changing climate on Norway spruce in Sweden and northern Europe. According to our results, extreme climate events like spring temperature backlashes and summer drought will increase in frequency and duration. In combination with a raised mean temperature, climate extremes will negatively precondition trees (i.e. increase their susceptibility) to secondary damage through pests and pathogens. Decreased forest vitality also makes stands more susceptible to windthrow. Storm damage is discussed based on a $100 \mathrm{yr}$ storm damage record for Sweden. Marginally increased frequencies and windspeeds of storms may cause disproportionate increases in windthrow. Increased economic hazards can be expected from a combination of the increased volumes of wind-thrown timber, and a greater likelihood of additional generations of spruce bark beetle Ips typographus (further encouraged by the increase in fallen timber), as a result of a changing climate with warmer summers.
\end{abstract}

KEY WORDS: Drought $\cdot$ Frost $\cdot$ Windstorm damage $\cdot$ Insect damage $\cdot$ Modelling $\cdot$ Forestry

\section{BACKGROUND}

Forestry in the Nordic countries is based on coniferous trees and is of major societal importance. The boreal forests of Finland and Sweden account for a large part of the European coniferous forest, e.g. $60 \%$ of the coniferous forest within the EU (as of 2003) (MCPFE \& UNECE/FAO 2003). About $55 \%$ of Swedish land area is covered by forest and $>95 \%$ of the productive forests are used for forestry (Statistical Yearbook of Forestry 2004). The importance of forestry in the national and rural economy is funda- mental, providing jobs and income for forest owners, forest workers and logging firms as well as a whole range of forestry-related services and forest industries. In 1996 the forest industrial cluster was responsible for $23 \%$ of industry turnover, $27 \%$ of added value, $26 \%$ of industrial employment, $33 \%$ of industrial export and $70 \%$ of the Swedish net export (Petäjä \& Littenheim 2005). In 2003, the value of exports from the Swedish forestry sector (part of the forest industrial cluster) was 109 billion Swedish Krone (SEK), and this accounted for $13 \%$ of total exports (Statistical Yearbook of Sweden 2004). 
Swedish forestry is based, mainly on 2 native species: Norway spruce Picea abies (L.) Karst. and Scots pine Pinus sylvestris L. Norway spruce and Scots pine constitute 42 and $39 \%$ of the standing volume of forest trees, respectively-in total, 30553 million $\mathrm{m}^{3}$ standing volume over bark (Statistical Yearbook of Forestry 2004). Forests are intensely managed and mainly mono-cultural: large areas are planted after felling or scarified to facilitate natural rejuvenation, and stands are repeatedly thinned to ensure optimal growth before clear-felling (Statistical Yearbook of Forestry 2004).

One aspect of the forestry sector that sets it apart from most other industrial sectors is its long-term planning horizon; in practice, a full tree generation is in the order of 70 to $120 \mathrm{yr}$, indeed about the same order of duration as the time-frame of most climate change scenarios. A complicating factor is that today's management decisions on rejuvenation, planting and choice of species are likely to have significantly different outcomes in future climates than in the climates that current practices were devised to handle.

Studies of climate change impacts on European boreal forests have largely focused on direct changes in forest productivity or on projected changes in the geographical distribution of different biomes or major forest types (Sykes et al. 1996, Saxe et al. 2001, Karnosky 2003), and to a lesser degree on indirect impacts. Several studies have shown that a doubled $\mathrm{CO}_{2}$ concentration in the atmosphere is likely to cause major shifts in the distribution of forest types in northern Europe. Modelling assessments by Sykes et al. (1996) and Bradshaw et al. (2000) point to a northern movement of the boundary between the nemoral and boreo-nemoral forest in the order of $1000 \mathrm{~km}$, as does a biogeographical assessment of changes in range of Norway spruce based on the shift the $-2^{\circ} \mathrm{C}$ isotherm for the coldest winter month (Dahl 1998), which by and large defines the natural nemoral/boreo-nemoral boundary. While such assessments may seem very alarming from a forestry perspective (because the forest industry is so dependent on Norway spruce and Scots pine), it should be borne in mind that the natural range of forest trees not only reflects climate as such, but also differences in competition between species over several life cycles (Loehle \& Leblanc 1996). From a practical forestry perspective the range-change issue is probably not such a severe problem, as most forests are production forests that to a high degree are planted and managed ecosystems. Norway spruce is currently grown outside its natural range in many parts of Europe, albeit with a higher growth rate and attendant earlier maturing and a shorter life span owing to, inter alia, an increased sensitivity to windstorm damage. Thus, climate change impact on disturbance regimes and tree vitality is probably of more importance, from a practical perspective, than a change in range extent for e.g. Norway spruce (e.g. Fleming 1996). Preconditioning factors affecting tree vitality are often long-term, low intensity stresses of high frequency, but can also be the reverse of this (i.e. high intensity stresses of low frequency), e.g. extreme weather, events (Warin 1987 , Stjernquist \& Selldén 2002).

\section{IMPACTS OF CLIMATE EXTREMES ON FORESTRY IN BOREAL EUROPE}

Projected climate change implies not only a change in mean climate parameters, such as temperature or precipitation, but also that such a change will result in changes in the frequency and magnitude of extreme weather events (Waggoner 1989, Brabson \& Palutikof 2002, Kjellström 2004). The fact that climate extremes are often defining for many biological, as well as technical, systems is a cause for concern and one of the rationales for the EU-funded 'Modelling the Impact of Climate Extremes' (MICE) Project (Kundzewicz et al. 2001).

The objective of the boreal forestry component within MICE has been to assess how changes in climate extremes may affect Scandinavian forestry through impacts on tree vitality or windstorm damage, as well as to assess the potential for insect damage by spruce bark beetles Ips typographus (L.), on Norway spruce. Norway spruce was chosen because of its economic importance, and because tree production and vitality are closely connected to a number of factors directly or indirectly related to climate. The starting point for the study is that tree vitality is affected by, inter alia, drought and frost, and vitality in turn affects tree susceptibility to windthrow and insect attack (Persson 1975, Kramer et al. 2000, Nielsen 2001, Jönsson et al. 2004a). Spruce bark beetle attack is further favoured by warmer summers, and by the increased availability of food and brood trees subsequent to windstorm felling (Fig. 1).

In common with other projects within MICE, we have used present-day runs of the SRES control scenario for the period 1961-1990 and 2 (A2 and B2) future scenario runs for 2070-2100 (Nakicenovic \& Swart 2000) of the Hadley Centre regional climate model HadRM3H to study direct and indirect effects of climate change.

\subsection{Drought and frost damage as preconditioning factors}

Drought stress/damage and frost damage may reduce tree vitality, and both factors are likely to change in terms of location, frequency and magnitude in a 


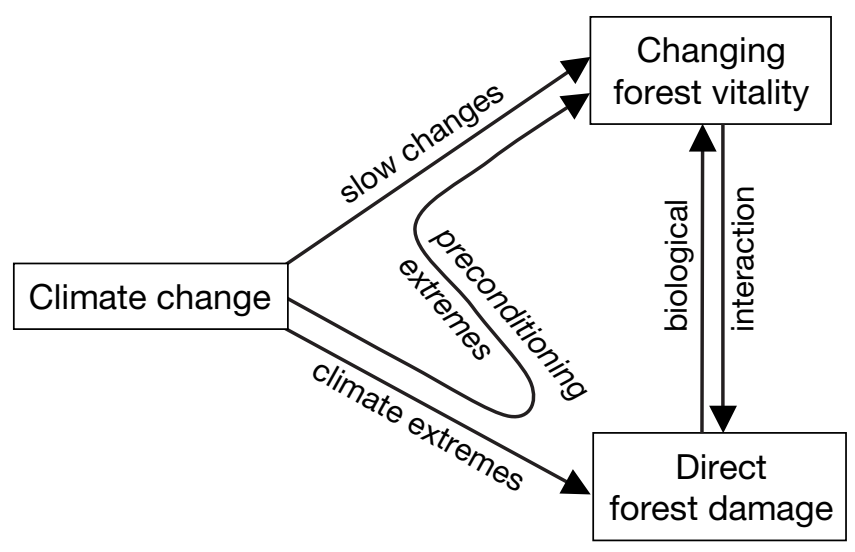

Fig. 1. Conceptual model of impacts of climate extremes and raised mean temperature on forest vitality. Raised mean temperature affects tree vitality through slow changes in growth conditions due to temperature increase, increased $\mathrm{CO}_{2}$ fertilisation and changes in soil nutrient availability. Depending on tree species, these effects may be positive or negative for tree vitality. Tree vitality is negatively affected by preconditioning extremes, e.g. frost spells during spring and dry spells during summer. A decreased vitality makes trees more sensitive to attack by pest and pathogens, e.g. spruce bark beetle. Direct forest damage is caused by strong windstorms. Wet soils and winters without frozen ground enhance the effect. Fallen trees are a good brooding material for spruce bark beetles

future climate. With regard to drought risks, it may be noted that Norway spruce has a very superficial root system that, depending on local site conditions, can make it sensitive to drought or changes in soil water regime (von Röhrig 1966, Köstler et al. 1968, Puhe 1994, 2003, Sverdrup et al. 2005). Drought is currently limiting the competitive advantage of Norway spruce in SE Sweden (cf. Nilsson 1996).

Changes in summer-late summer drought risk have been assessed by comparing changes in the 75th percentile over the $30 \mathrm{yr}$ period of the number of dry days (defined as days with a precipitation $<0.5 \mathrm{~mm}$ ) during the period 16 July to 15 September (Fig. 2). It is apparent that summer drought conditions will increase in duration for large parts of Europe north of the Alps, and that the 75th percentile drought days will only decrease in small areas at (mainly) higher latitudes. The implications of the scenario depicted in Fig. 2 will be that larger areas will be faced by drought stress, and that areas currently suffering intermittent drought stress will be subject to stress more frequently as well as by more severe, i.e. longer, droughts. However, more detailed evaluation will have to take into account seasonal variability in climate, as well as regional/local edaphic and other factors, and relate these to growth or physiological proxies.

Frost damage occurs in trees when the temperature is lower than their frost hardiness. Damage ranges from the reversible, at a physiological cost for repair, to non-reversible damage causing necrosis to parts of the tree or its death (Larcher 1981, Sakai \& Larcher 1987). Frost hardiness depends on the phenologic state, and varies over the year and within season depending on how the state of hardening/de-hardening has developed (Skre 1988, Kramer et al. 2000, Bigras et al. 2001, Greer et al. 2001). Thus, fixed thresholds are of little use to evaluate frost risks. We have evaluated the frost damage risks for the A2 and B2 scenarios by using different indices which were based on: the start of dehardening in spring, the timing of bud burst, the severity of the temperature backlash, and the cold hardiness level (Jönsson et al. 2004b). Indices were based on (1) the number of temperature backlashes after the onset of de-hardening, (2) accumulated degree days between the onset of de-hardening and a temperature $<-2^{\circ} \mathrm{C}$, (3) the number of temperature backlashes after bud burst, and (4) the number of days below a temperature-adjusted spring and autumn hardiness level (cf. Jönsson et al. 2004b).

Generally, the assessment showed a reinforced north-south spring backlash gradient, where the risk for spring frost damage increases in the south. Fig. 3 illustrates the change in spring backlash frequency. For both scenarios there is what may be regarded as a frost risk paradox, in that (regionally) the risk for spring frost damage appears to increase significantly in future milder climates. This increase in risk is due to the combined effects of earlier de-hardening and early spring frosts. The risk for autumn frost damage, currently affecting middle and northern Sweden, decreases in both scenarios.

\subsection{Windstorm damage}

Windthrow damage, although not always specified separately by insurance companies, is one of the major consequences of storm events (Kristensen et al. 2000, Mayer \& Schindler 2002, Sacre 2002, Braun et al. 2003). On a European scale windstorm is responsible for $53 \%$ of the total damage to forests (Schelhaas et al. 2003).

During the last decade, there has been intense discussion on the existence of evidence for changes in storm frequency in the North Atlantic and adjacent European areas, and if such a change (if any) is due to an anthropogenic climate change. The analyses and literature reviews by both Carretero et al. (1998) and Heino et al. (1999) concluded that there is no consistent observational evidence for any persistent trend in storm frequency for the North Atlantic and European areas during the 20th century. Instead, the end of the 19 th century and beginning of the 20th century seem to have been just as stormy in northern Europe as were 


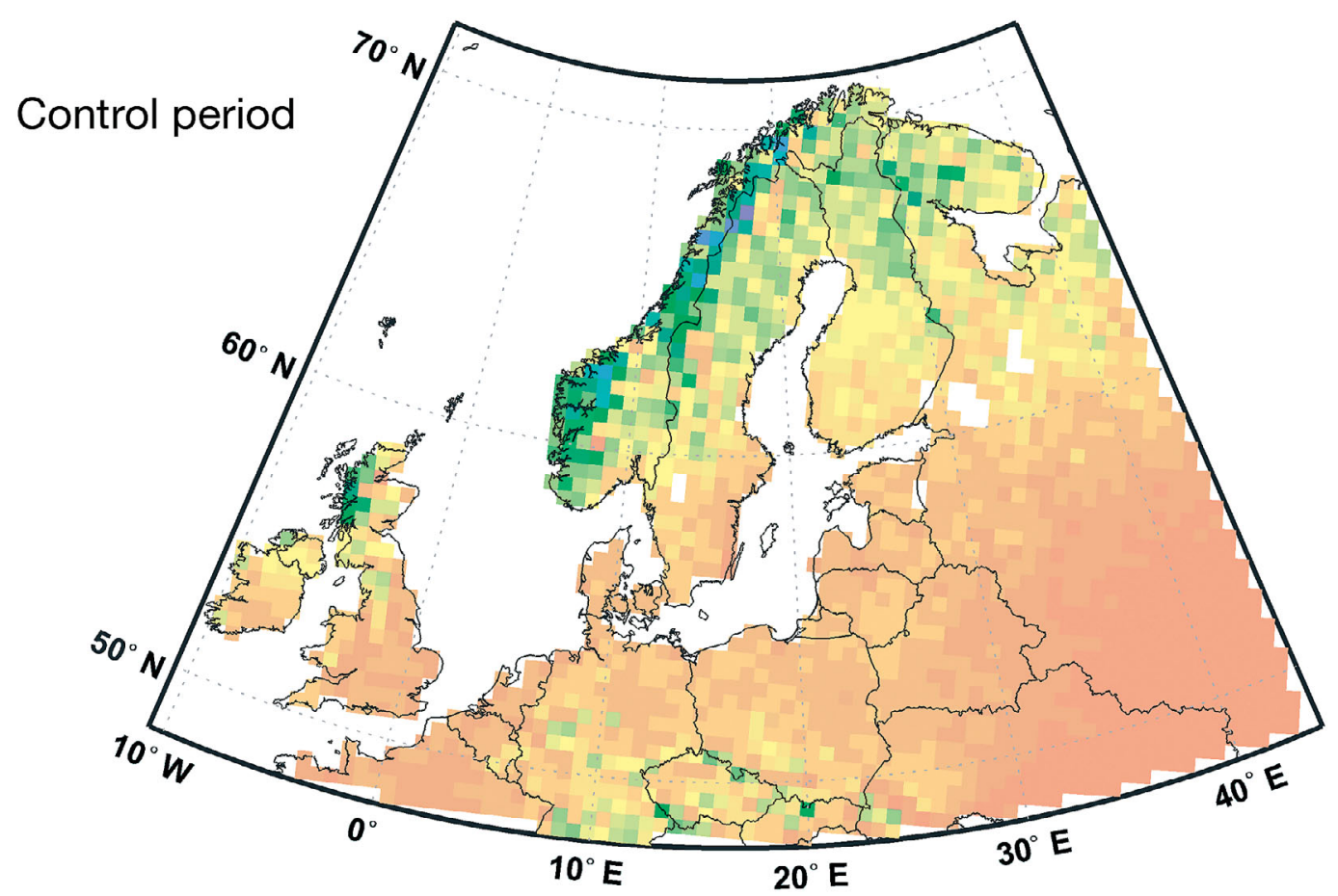

A
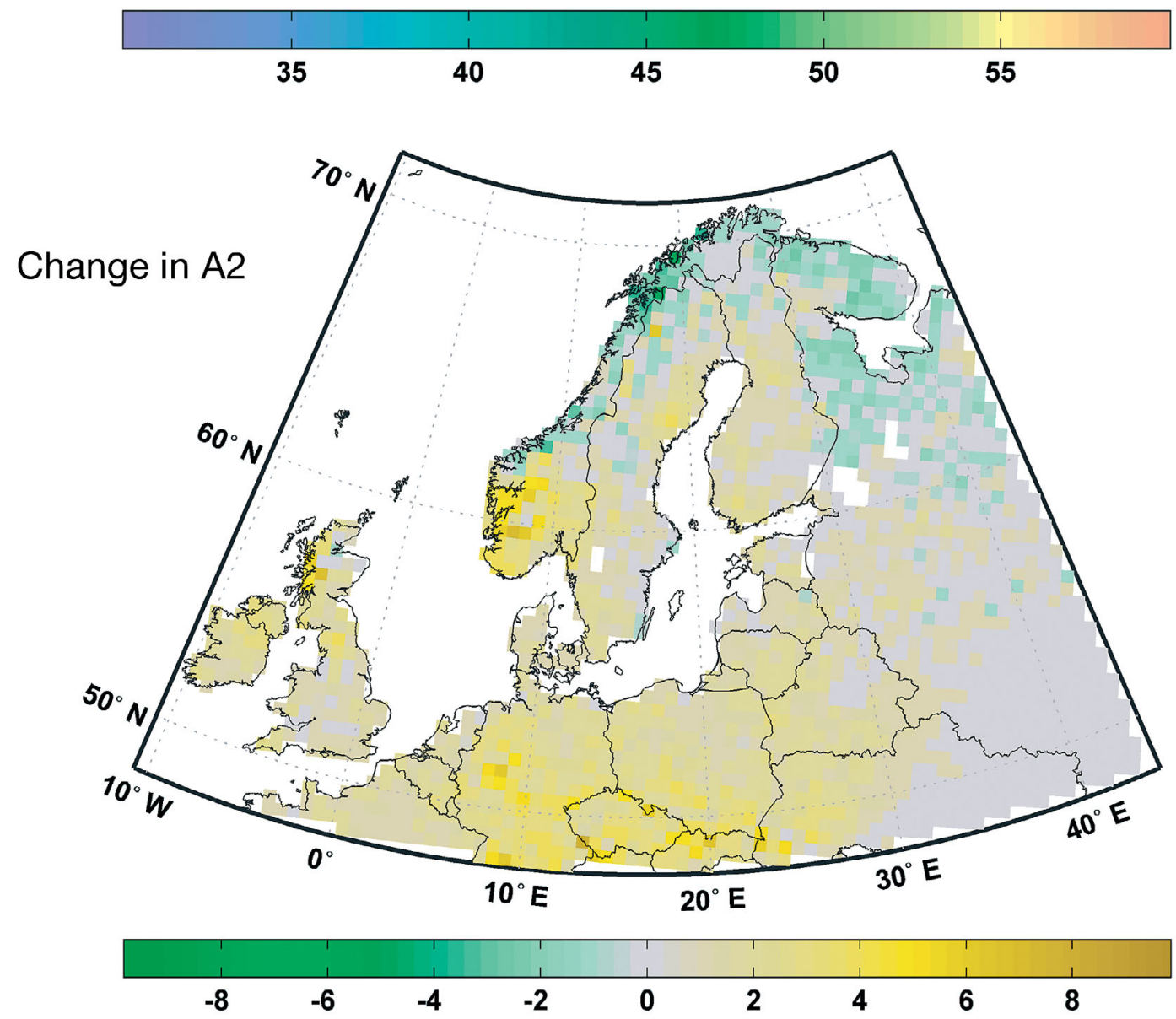

Fig. 2. (A) 75th percentile of number of dry days between 16 July and 15 September during 1961-1990 (control period). (B) Changes in 75th percentile of number of dry days between 16 July and 15 September over the 30 yr period 2070-2099 for the SRES A2 scenario 
Control period

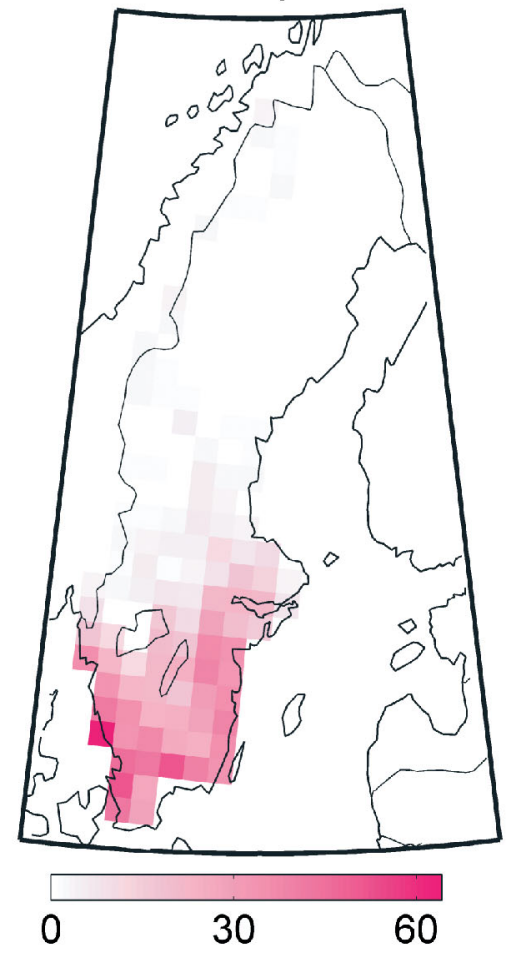

A2

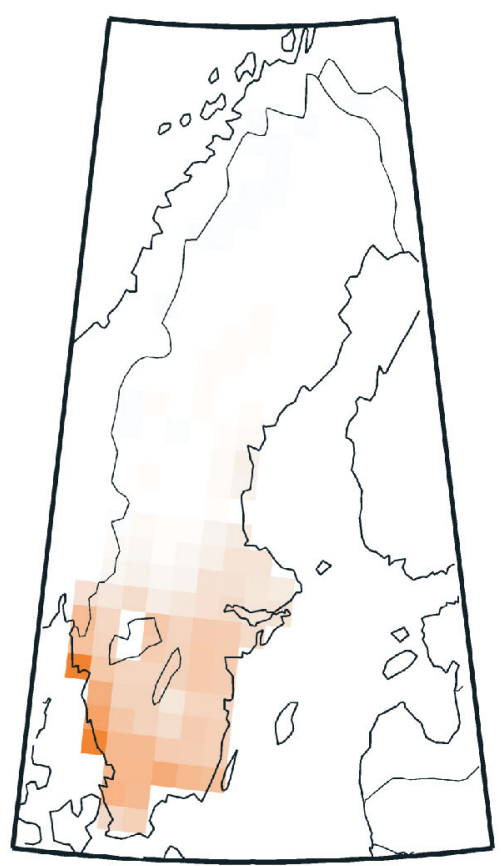

B2

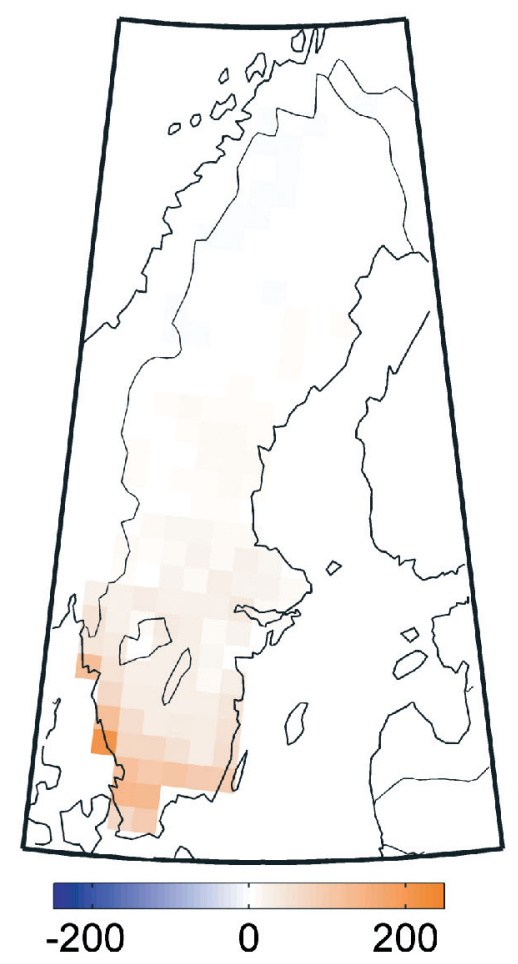

Fig. 3. Frequency of spring backlashes for the 1961-1990 control period and changes in spring backlash frequency in SRES A2 and B2 scenarios (Jönsson et al. 2004b)

recent decades. Alexandersson et al. (2000) reached a similar conclusion based on calculations of geostrophic wind over the North Sea and Baltic regions, where they found a long-term variation on the century scale but with no overall long-term trend in annual mean wind speed during the last 100 to $150 \mathrm{yr}$; furthermore, Bärring \& von Storch (2004) analysed indicators of storminess over southern Scandinavia and concluded that the number of storms has been remarkably stable for the last $200 \mathrm{yr}$.

On the other hand, published damage assessments (Munich Re 1990, 1996, 2002) have shown a considerable increase in the frequency of severe windstorm damage during the late 20th century, and would at a first glance seem to indicate an increase in windstorm frequency. There are, however, several other factors, such as land use changes, changes in stand age and structure, forestry practices and air pollution regimes, that change over time in ways that may alter the windthrow susceptibility of forests.

A complete database on windstorm damage in Sweden during the last century (1901-2000) was compiled in order to assess whether storm damage has increased over time and, if such an increase was present, how it was related to changed windstorm conditions (Nilsson et al. 2004). We used data from county damage assessments performed by the Regional Forestry Boards
(Skogsvårdsstyrelserna) and used the same age class boundaries as the National Forest Inventory (Riksskogstaxeringen) and an age threshold, $41 \mathrm{yr}$, as the age by which a stand will have normally been thinned and is tall enough to exert significant aerodynamic resistance and be at risk of windthrow (cf. Møller 1957, Persson 1975).

Storm damage to forest occurred relatively frequently during $51 \mathrm{yr}$ in the last century (up to and including the year 2000), and was caused by 77 individual windstorms (Fig. 4). Total storm losses during that century were 110.7 million $\mathrm{m}^{3}$; however, $49 \%$ of volume losses was caused by 5 storm events only (Nilsson et al. 2004). Storm damage appears to be greater in southern Sweden than in the northern part of the country. Furthermore, an increase in storm damage over the country as a whole during the latter part of the last century is probably not a result of increased storm frequency or magnitude, but rather an effect of both a larger proportion, and a larger absolute volume, of forests within the age classes prone to storm damage (Nilsson et al. 2004). Changes in forest management may be a further contributing factor.

The analysis was carried further for southern Sweden, where it was possible to normalise loss data to the total volume of damaged timber per year, in any 


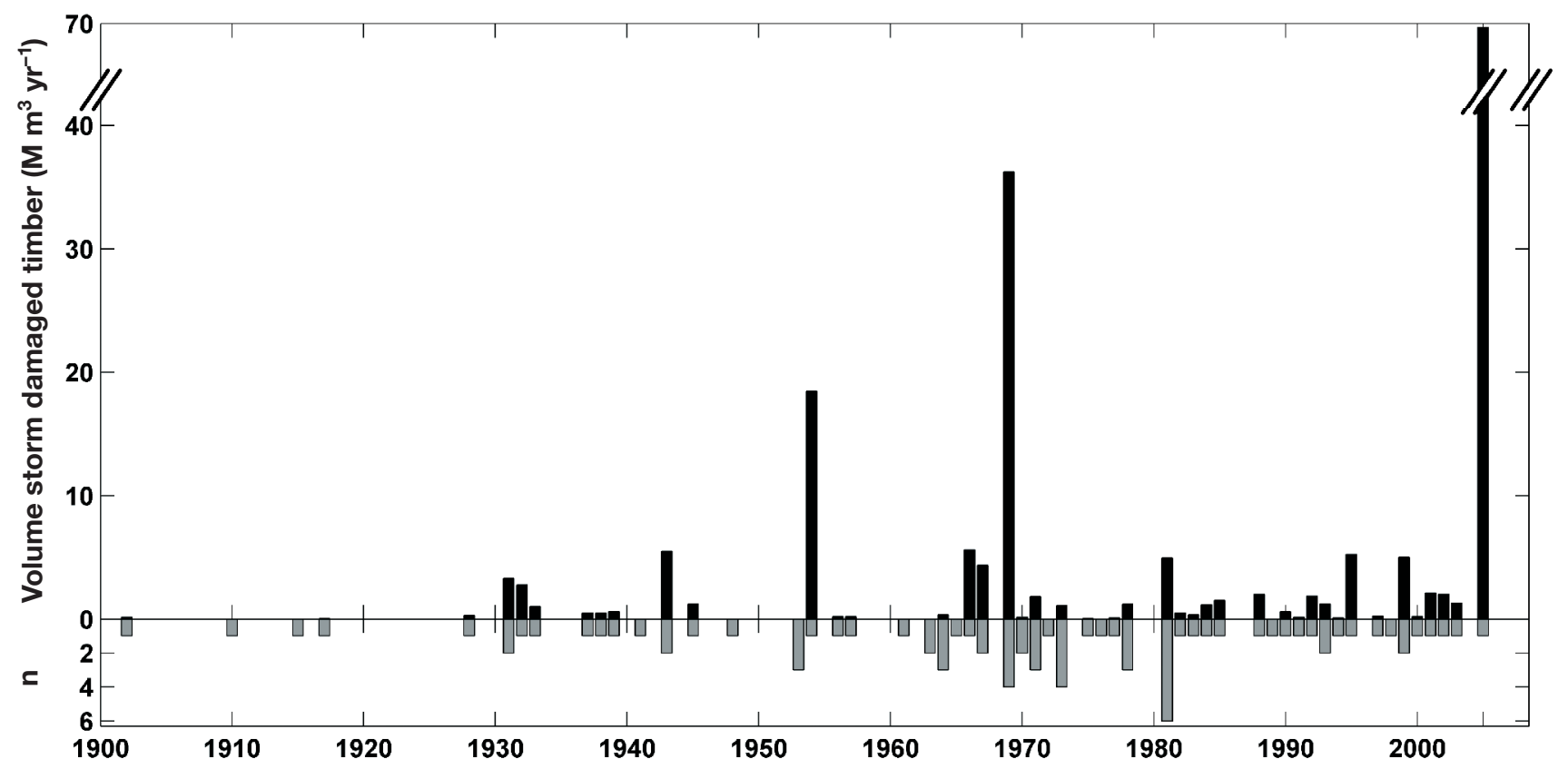

Fig. 4. Annual total numbers (n) of recorded forest-damaging storms in Sweden from 1901 to January 2005 (grey bars), and annual damaged volume of timber expressed as million $\mathrm{m}^{3}$ standing volume (black bars) (based on Nilsson et al. 2004, updated from 2001 to January 2005)

given county and year, as a proportion of the area of productive forest stands older than $41 \mathrm{yr}$ in that county (total volume measured as $\mathrm{m}^{3}$ standing volume [stem volume over bark from stump to tip]; damaged timber units: $\mathrm{m}^{3} \mathrm{yr}^{-1}$; productive forest stands defined as stands with growth $>1 \mathrm{~m}^{3} \mathrm{yr}^{-1}$ ). This normalisation allowed unbiased comparisons over time both within and between counties, such that the effects of afforestation and ageing forest will not influence the analysis. The 2 southernmost counties had a disproportionate amount of windthrow damage (Fig. 6), tentatively interpreted as an effect of milder winters with attendant higher respiratory losses for Norway spruce (in turn negatively affecting tree vitality, cf. Dahl 1998), and lack of frozen soil conditions anchoring stands.

\subsection{Conditions affecting spruce bark beetle damage}

Bark beetle damage to spruce trees is one of the major biological causes of loss to forestry in Europe (Schelhaas et al. 2003). Mass occurrences of Norway spruce bark beetle Ips typographus L. are encouraged by the availability of weakened or dead trees for food and as breeding substrate, as well as by suitable climatic conditions (Annila 1969, Wermelinger 2004) temperature, for example, exercises a strong influence on bark beetle breeding (Annila 1969). Beetle damage on a catastrophic level was associated with the presence of large volumes of windthrown trees after the 1969 storms in Sweden (Göthlin et al. 2000, cf. Nilsson et al. 2004).

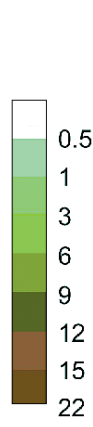

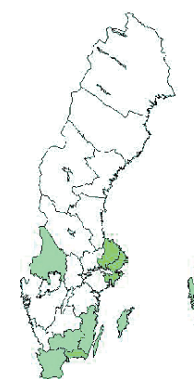

1931

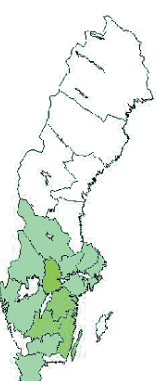

1943

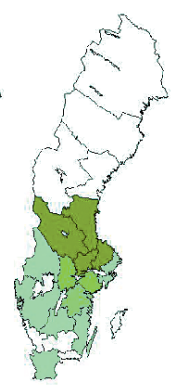

1954

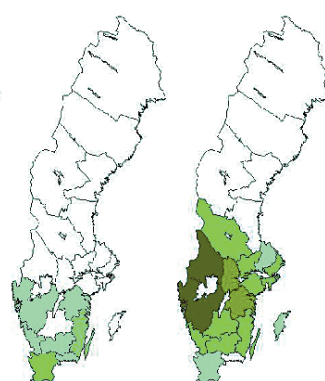

1967

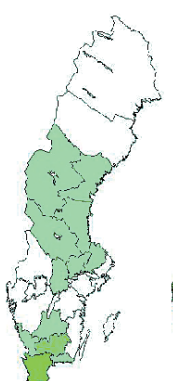

1981

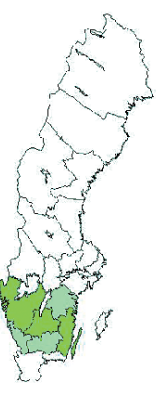

1995

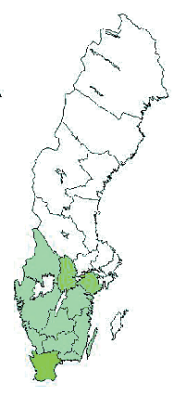

1999

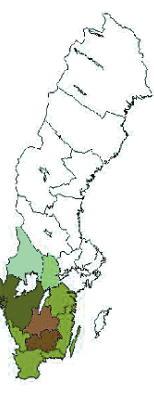

2005

Fig. 5. Annual storm damage per county expressed as million cubic metre standing volume $\left(\mathrm{M} \mathrm{m}^{3}\right)$, for the 9 years with highest amount of damage (based on Nilsson et al. 2004, updated from 2001 to January 2005) 
In a future climate with elevated temperatures, the potential for bark beetle damage in spruce forestry may increase. Currently, most parts of Scandinavia have only 1 swarming period during summer and the production of a second generation occurs only infrequently in the southernmost part (Annila 1969, Harding \& Ravn 1985). In a warmer climate, the temperature-dependent development from egg to insect will occur faster, thereby increasing the risk for an additional generation to reach swarming maturity during summer. A model was developed to assess the effect of climate change on spruce bark beetle dynamics. Temperature-dependent swarming activity and thermal requirement for development was modeled using temperature thresholds for swarming and temperature sums for beetle development (Jönsson et al. 2004a). Results show that the risk of a second swarming will increase substantially, from a yearly frequency of 0.1 for the control period to 0.7 and 1 for scenarios B2 and A2, respectively (Fig. 7).

\section{DISCUSSION AND CONCLUSIONS}

When examining factors that affect Norway spruce vitality, susceptibility to windthrow, or vulnerability to bark beetle damage (cf. Fig. 1) we note that several aspects of modelled future climate is likely to negatively affect Norway spruce forests. The risk and duration of long drought periods will increase. Such drought effects are likely to be further enhanced in areas with high atmospheric nitrogen deposition, as this favours the development of reduced and superficial root systems (Majdi \& Kangas 1997). Similarly, in areas with high exposure to tropospheric ozone, as is the case for large parts of Europe and southern Scandinavia (Hjellbrekke \& Solberg 2004), negative drought effects may be further exacerbated as ozone damage to foliage, i.e. stomata damage, results in reduced capacity to conserve water (Maier-Maerker 1997, 1999). The combined stress effects of ozone, nitrogen deposition and drought have been reported to increase the bark beetle activity by up to $50 \%$ (Eratough Jones et al. 2004). The impact of climate change on regional ozone production and its interaction with drought requires further study.

The likelihood of frost damage poses a mixed picture: the southern parts of Sweden will be exposed to an increased risk of spring frost damage, while the risk of autumn frosts will decrease in the middle and
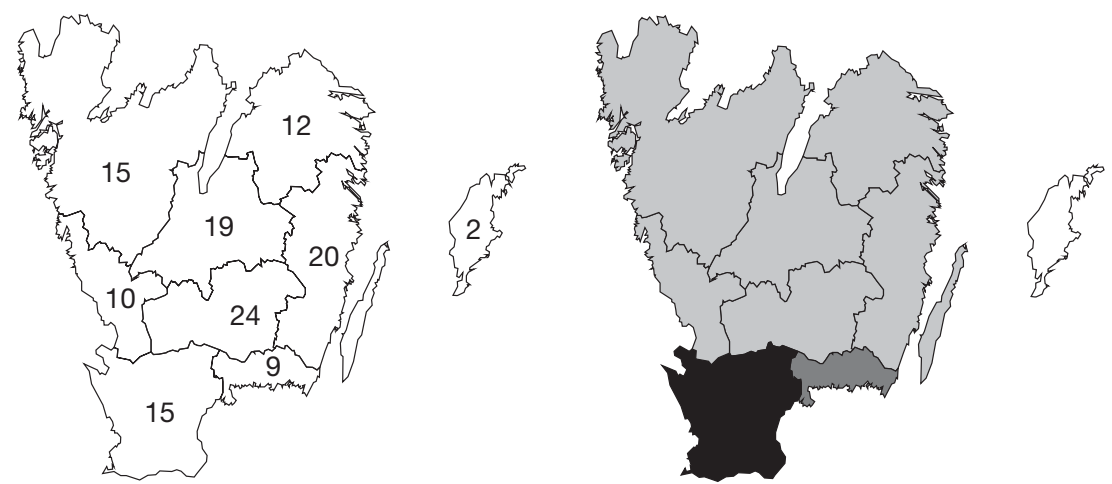

Total damaged timber $\left(\mathrm{m}^{3} \mathrm{ha}^{-1} \mathrm{yr}^{-1}\right)$

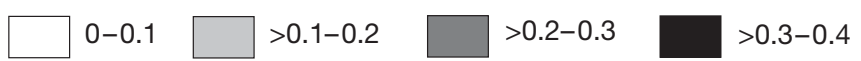

Fig. 6. No. of windstorms causing windthrow damage in southern Sweden during the 20th century, and total volume damaged timber (standing volume). In total, 47 storms occurred in the $26 \mathrm{yr}$ with reported windthrow damage
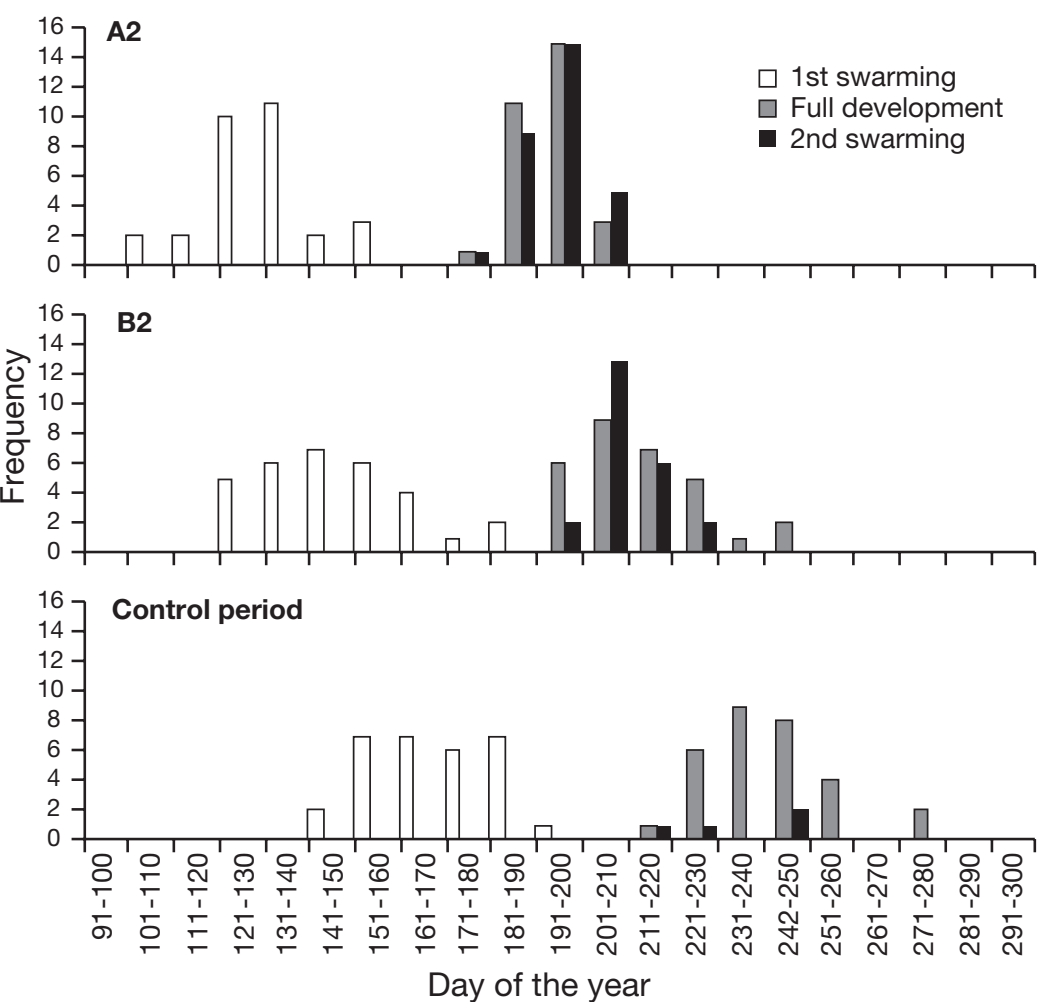

Fig. 7. Occurrence and yearly frequency of the first swarming, full development and second swarming for spruce bark beetle in southern Sweden for the control period (1961-1990) and SRES A2 and B2 scenarios 
northern parts of Sweden. Spring frost damage will affect not only the vitality of larger trees but also, and perhaps more importantly, the establishment phase of seedlings and planted trees. Nitrogen deposition, once again, poses an additional stress factor as it reduces frost tolerance in plants (Skre 1988, Thomas \& Ahlers 1999, Jönsson \& Welander 2002, Jönsson et al. 2004c); current deposition is greatest in the southwestern and southern parts of Sweden (Sverdrup et al. 2002).

Observed storm damage to Swedish forests has increased over the years (Nilsson et al. 2004). This is interpreted to be due to a combination of factors, chiefly an increasing proportion of forests within the age susceptible to windthrow, and more pure spruce stands as opposed to mixed stands - an effect of modern silviculture and afforestation of former agricultural land (Statistical Yearbook of Forestry 2004, Jönsson 1996), rather than as an effect of changes in storm frequency or intensity (cf. Bärring \& von Storch 2000). Proportionally larger storm damage per unit area in 2 southernmost counties of Sweden is tentatively interpreted as reflecting a higher susceptibility to windthrow in spruce growing outside the $-2^{\circ} \mathrm{C}$ isotherm for the coldest winter month, where increased respiratory losses during winter reduce tree vitality (cf. Dahl 1998), and unfrozen soil conditions reduce tree stability (Nilsson et al. 2004).

Results of Leckebusch \& Ulbrich (2004) and Leckebusch et al. (2006, this issue) indicate that both the frequency and intensity of severe windstorm events will increase slightly in northern continental Europe and southern Scandinavia. Huge windthrow losses caused by the 8 January 2005 storm in southern Sweden (equivalent to $63 \%$ of the total volume damaged during the previous century) could be seen as an example of some of the problems that may face future forestry. The storm was not outside what may be regarded as the normal range of intensity, but it clearly belonged to the higher end of the intensity distribution. As such, this storm illustrates the point that minor increases in storm intensity may cause disproportionate increases in damage. A slight increase in future storm intensities, coupled with increased prevalence of forests of largely monocultural character and in age classes prone to windthrow, gives cause for concern. Damage is likely to arise both directly from storms, and indirectly where food and brood tree availability increases in a future climate. A warmer climate will also favour earlier swarming and second broods of spruce bark beetles, as well as improved winter survival for the beetle. Various forms of forest management could, however, reduce storm damage susceptibility (Gardiner \& Quine 2000), and thus the amount trees available to spruce bark beetles following storms.
There is a need for better models of climate change impacts on forestry, in particular for models that are able to handle coupled impacts of the kind described above (cf. Ayres \& Lombardero 2000). This is particularly true for the boreal forest, which supplies a major industrial sector. One of the important outcomes from a broad-based seminar held for forestry stakeholders was the recognition of the need for improved impact assessments (with explicit declarations about the uncertainties involved) to allow for the inclusion of climate change effects in long-term forest planning and management decisions.

Acknowledgements. This research has been carried out within the 'Modelling the Impact of Climate Extremes' (MICE) project, funded by the European Commission under the 5th Framework Programme of Scientific Research (contract EVK2-CT-2001-00118).

\section{LITERATURE CITED}

Alexandersson H, Tuomenvirta H, Schmith T, Iden K (2000) Trends of storms in NW Europe derived from an updated pressure data set. Clim Res 14:71-73

Annila E (1969) Influence of temperature upon the development and voltinism of Ips typographus (L.) (Coleoptera, Scolytidae). Ann Zool Fenn 6:161-208

Ayres MP, Lombardero MJ (2000) Assessing the consequences of global change for forest disturbance from herbivores and pathogens. Sci Total Environ 262:263-286

Bärring L, von Storch H (2004) Scandinavian storminess since about 1800. Geophys Res Lett 31:L20202, doi:10.1029/ 2004GL020441

Bigras FJ, Ryyppö A, Lindström A, Stattin E (2001) Cold acclimation and deacclimation of shoots and roots of conifer seedlings. In: Bigras FJ, Colombo SJ (eds) Conifer cold hardiness. Kluwer Academic Publishers, Dordrecht, p 57-88

Brabson BB, Palutikof JP (2002) The evolution of extreme temperatures in the Central England temperature record. Geophys Res Lett 29:2163, doi:10.1029/2002GL015964

Bradshaw RHW, Holmquist BH, Cowling AS, Sykes M (2000) The effect of climate change on the distribution and management of Picea abies in southern Scandinavia. J Can For Res 30:1992-1998

Braun S, Schindler C, Volz R, Fluckiger W (2003) Forest damages by the storm 'Lothar' in permanent observation plots in Switzerland: the significance of soil acidification and nitrogen deposition. Water Air Soil Pollut 142:327-340

Carretero JC, Gomez M, Lozanom I, de Elvira AR and 27 others (1998) Changing waves and storms in the northeast Atlantic? Bull Am Meteorol Soc 79:741-760

Dahl E (1998) The phytogeography of northern Europe (British Isles, Fennoscandia and adjacent areas). Cambridge University Press, Cambridge

Eatough Jones M, Paine TD, Fenn ME, Poth M (2004) Influence of ozone and nitrogen deposition on bark beetle activity under drought conditions. For Ecol Manage 200: $67-76$

Fleming RA (1996) A mechanistic perspective of possible influences of climate change on defoliating insects in North America's boreal forests. Silva Fenn 30:281-294 
Gardiner BA, Quine CP (2000) Management of forests to reduce the risk of abiotic damage - a review with particular reference to the effects of strong winds. For Ecol Manage 135:261-278

Göthlin E, Schroeder LM, Lindelöw A (2000) Attacks by Ips typographus and Pityogenes chalcographus on windthrown spruces (Picea abies) during the two years following a storm felling. Scand J For Res 15:542-549

Greer DH, Leinonen I, Repo T (2001) Modelling cold hardiness development and loss in conifers. In: Bigras FJ, Colombo SJ (eds) Conifer cold hardiness. Kluwer Academic Publishers, Dordrecht, p 89-120

Harding S, Ravn HP (1985) Seasonal activity of Ips typographus L. (Col. Scolytidae) in Denmark. Z Angew Entomol 99:121-131

Heino R, Brazdil R, Førland E, Tuomenvirta H and 7 others (1999) Progress in the study of climate extremes in northern and central Europe. Clim Change 42:151-181

Hjellbrekke AG, Solberg S (2004) Ozone measurements 2002. EMEP/CCC-Report 2/2004, Norsk Institutt for Luftforskning, Kjeller

Jönsson AM, Welander T (2002) Sensitivity to frost and drought. In: Sverdrup H, Stjernquist I (eds) Developing principles and models for sustainable forestry in Sweden. Kluwer Academic Publishers, Dordrecht, p 213-316

Jönsson AM, Bärring L, Nilsson C, Stjernquist I, Schlyter P (2004a) Increased bark beetle damage due to change in climate extremes? EGU 1st Gen Assembly, Nice, April 25-30, Session CL13: Extreme Climate Events Observations, Modelling and Impacts. Geophys Res Abstr 6: available at www.cosis.net/members/meetings/programme/ view.php?p_id=79

Jönsson AM, Linderson ML, Stjernquist I, Schlyter P, Bärring L (2004b) Climate change and the effect of frost damage causing temperature backlashes in Picea abies. Global Planet Change 44:195-207

Jönsson AM, Ingeslev M, Raulund-Rasmussen K (2004c) Frost sensitivity and nutrient status in a fertilized Norway spruce stand in Denmark. For Ecol Manage 201:199-209

Karnosky DF (2003) Impacts of elevated atmospheric $\mathrm{CO}_{2}$ on forest trees and forest ecosystems: knowledge gaps. Environ Int 29:161-169

Kjellström E (2004) Recent and future signatures of climate change in Europe. Ambio 33:193-198

Kramer K, Leinonen I, Loustau D (2000) The importance of phenology for the evaluation of impact of climate change on growth of boreal, temperate and Mediterranean forest ecosystems: an overview. Int J Biometeorol 44:67-75

Kristensen L, Rathmann O, Hansen SO (2000) Extreme winds in Denmark. J Wind Eng Ind Aerodyn 87:147-166

Köstler NJ, Brückner E, Bibelreiter H (1968) Die Wurzeln der Waldbäume. Parey, Hamburg

Kundzewicz ZW, Parry ML, Cramer W, Holten JI and 6 others (2001) The European region. In: McCarthy JJ, Canziani OF, Leary NA, Dokken DJ, White KS (eds) Climate change 2001: impacts, adaptation and vulnerability. Contribution of Working Group II to the Third Assessment Report of the Intergovernmental Panel on Climate Change. Cambridge University Press, Cambridge, p 640-692

Larcher W (1981) Effects of low temperature stress and frost injury on plant productivity. In: Johnson CB (ed) Physiological processes limiting plant productivity. Butterworth \& Heinemann, London, p 253-269

Leckebusch GC, Ulbrich U (2004) On the relationship between cyclones and extreme windstorm events over Europe under climate change. Global Planet Change 44: 181-193
Leckebusch GC, Koffi B, Ulbrich U, Pinto JG, Spangehl T, Zacharias S (2006) Analysis of frequency and intensity of European winter storm events from a multi-model perspective, at synoptic and regional scales. Clim Res 31:59-74

Loehle C, Leblanc D (1996) Model-based assessments of climate change effects on forests: a critical review. Ecol Model 90:1-31

Maier-Maercker U (1997) Experiments on the water balance of individual attached twigs of Picea abies (L.) Karst. in pure and ozone-enriched air. Trees 11:229-239

Maier-Maercker U (1999) Predisposition of trees to drought stress by ozone. Tree Physiol 19:71-78

Majdi H, Kangas P (1997) Demography of fine roots in response to nutrient applications in a Norway spruce stand in southwestern Sweden. Ecoscience 4:199-205

Mayer H, Schindler D (2002) Forest meteorological fundamentals of storm damages in forests in connection with the extreme storm 'Lothar'. Allg Forst Jagd Ztg 173:11-12

MCPFE \& UNECE/FAO (2003) State of Europe's forests. Ministerial Conference on the Protection of Forests in Europe. MCPFE Liaison Unit, Vienna

Møller CM (1957) Stormfahldets betdning før dansk skovbrug. Dan Skovføren Tidsskr 42:526-543

Munich Re (1990) Windstorm-new loss dimensions of a natural hazard. Munich Re Group, Munich

Munich Re (1996) Winter storms in Europe-Analysis of 1990 losses and future loss potential. Munich Re Group, Munich

Munich Re (2002) Winterstorms in Europe (II) - Analysis of 1999 losses and loss potentials. Munich Re Group, Munich

Nakicenovic N, Swart R (2000) Emission scenarios. A special report of Working Group III of the Intergovernmental Panel on Climate Change. Cambridge University Press, Cambridge

Nielsen CN (2001) Vejledning i styrkelse af stormfasthed og sundhed i nåletræbevoksninger. Dan Skovbrugs Tidsskr 86:216-263

Nilsson C, Stjernquist I, Bärring L, Schlyter P, Jönsson AM, Samuelsson H (2004) Recorded storm damage in Swedish forests 1901-2000. For Ecol Manage 199:165-173

Nilsson NE (1996) The forests. The Swedish national atlas. SNA Förlag, Stockholm

Persson P (1975) Windthrow in forests-its causes and the effect of forestry measures. PhD thesis, Royal College of Forestry, Stockholm

Petäjä P, Littenheim K (2005) The Swedish forest cluster. Jaakko Pöyry Consulting, Stockholm

Puhe J (1994) Die Wurzelentwicklung der Fichte (Picea abies) bei unterschiedlichen Bodenbedingungen. Forschungszentrum Waldökosysteme der Universität Göttingen, Göttingen

Puhe J (2003) Growth and development of the root system of Norway Spruce (Picea abies) in forest stands-a review. For Ecol Manage 175:235-273

Sacre C (2002) Extreme wind speed in France: the '99 storms and their consequences. J Wind Eng Ind Aerodyn 90: 1163-1171

Sakai A, Larcher W (1987) Frost survival of plants. Responses and adaptation to freezing stress. Ecological studies, Vol 62. Springer-Verlag, Berlin

Saxe H, Canell MGR, Johnsen Ø, Ryan MG, Vourlitis G (2001) Tree and forest functioning in response to global warming. New Phytol 149:369-400

Schelhaas JM, Nabuurs GJ, Schuck A (2003) Natural disturbances in the European forests in the 19th and 20th centuries. Global Change Biology 9:1620-1633

Skre O (1988) Frost resistance in forest trees: a literature survey. Medd Nor Inst Skogforsk 40:1-35 
Statistical Yearbook of Forestry (2004) Official statistics of Sweden. National Board of Forestry, Jönköping

Statistical Yearbook of Sweden (2004) Official Statistics of Sweden, Örebro

Stjernquist I, Selldén G (2002) Mechanisms and systems of multiple stress. In: Sverdrup H, Stjernquist I (eds) Developing principles and models for sustainable Forestry in Sweden. Kluwer Academic Publishers, Dordrecht, p 197-204

Sverdrup H, Hagen-Thorn A, Holmqvist J, Wallman P, Warfvinge P, Walse C, Alveteg M (2002) Biogeochemical processes and mechanisms. In: Sverdrup H, Stjernquist I (eds) Developing principles and models for sustainable forestry in Sweden. Kluwer Academic Publishers, Dordrecht, p 91-100

Sverdrup H, Stjernquist I, Thelin G, Holmqvist J, Wallman P, Svensson M (2005) Application of natural, social and economical sustainability limitations to forest management, based on Swedish experiences. J Sust For 21: 145-174

Submitted: April 18, 2005; Accepted: February 25, 2006
Sykes M, Prentice C, Cramer W (1996) A bioclimatic model for the potential distribution of northern European tree species under present and future climates. J Biogeogr 23:303-2333

Thomas FM, Ahlers U (1999) Effects of excess of nitrogen on frost hardiness and freezing injury of above-ground tissue in young oaks (Quercus petrea and Q. robur). New Phytol 144:73-83

von Röhrig E (1966) Die Wurzelentwicklung der Waldbäume in Abhängigkeit von den ökologischen Verhältnissen. Forstarchiv 37:217-229

Waggoner PE (1989) Anticipating the frequency distribution of precipitation if climate change alters the mean. Agric For Meteorol 47:321-337

Warin RH (1987) Characteristics of trees predisposed to diestress causes distinctive stresses in phosyntate allocation. Bio Science 37:569-574

Wermelinger B (2004) Ecology and management of the spruce bark beetle Ips typographus - a review of recent research. For Ecol Manage 202:67-82

Proofs received from author(s): June 12, 2006 